\title{
Performance analysis of turbofan engine with additional combustion chamber fueled by alternative fuel
}

Presented paper is focused on the performance analysis of turbofan engine with additional combustion chamber fueled by alternative fuel. Additional combustion chamber was situated between high pressure turbine and low pressure turbine. Such configuration is also know under the name inter turbine burner (ITB). As an alternative fuels burn in additional combustion chamber were selected cryogenics fuels: liquid hydrogen and liquid methane. The main combustion chamber was supplied by conventional aviation fuel - kerosene. Thermodynamic model of turbofan engine with ITB was implemented in MATLAB environment. The problem of modeling an additional combustion chamber was presented. Analysis was carried out for take-off conditions. Obtained results indicate that implementation of ITB exert a positive influence on engine performance result in thrust increase.

Key words: alternative fuels, liquid hydrogen, liquid methane, inter turbine burner (ITB), turbofan engine

\section{Introduction}

The problem associated with the emission of harmful products of combustion of hydrocarbon fuels is an inherent element of any type of transport using fossil fuels. Emissions of greenhouse gases and other harmful substances to the atmosphere, generated by the aviation sector can be reduced by increasing the efficiency of the turbine engines, improving the quality of applied fuels, modification of the combustion chamber and injector assembly, or replacing conventional aviation fuel with alternative fuel.

First of all, applied fuel cannot negatively affect engine performance, as well as, should retain its properties in a wide range of changes of atmospheric conditions (pressure and temperature changes due to the increase of altitude). The properties of aviation fuel are determined directly by the content of hydrocarbons. Turbine engines during operations must ensure high-quality atomization and stable combustion process of continuous nature. The quality of the atomization process in the combustion chamber is influenced by the physical properties of the fuel such as density, viscosity and surface tension. Alternative fuels can differ significantly in composition compared to conventional fuels, therefore it is necessary to understand the effect of the physical and chemical properties of a given fuel on combustion process [1].

Alternative fuel implementation in transport will reduce the dependency of global economy on the basic energy sources of fossil fuel. Air traffic is increasing from year to year, so the key issue is to find a sustainable alternative fuel source that will keep fuel costs at reasonable level. Another very important problem is impact on the natural environment. The aircraft transport generate about $2 \%$ of carbon dioxide $\left(\mathrm{CO}_{2}\right)$ pollutants caused by human activity, and it is estimated by Intergovernmental Panel on Climate Change (IPCC) that this figure will reach $3 \%$ in 2050 year [10].

\section{Future of cryogenic fuels in aviation}

Long term solution related to alternative fuels application in aircraft engines will have drastically reduce emission of greenhouse gases to the atmosphere. Due to this requirement, application can find fuels with zero carbon content, such as liquid hydrogen $\left(\mathrm{H}_{2}\right)$ or those, with a low content of this chemical element, like liquid methane $\left(\mathrm{CH}_{4}\right)$ [2]. Application of cryogenic fuels in turbine engines, will involve modification of combustor chamber elements, fuel system, changes in the airframe configurations and huge alteration in infrastructure. It will be necessary to use a heat exchanger to evaporate the cryogenic stored fuel, before it injection and combustion [2,3]. Necessity of application well-insulated fuel tanks of considerable weight and volume will reduce the energy efficiency of aircraft during short range flights. It is estimated that in case of short range airplanes fueled by liquid hydrogen, the decrease in energy efficiency will amount to approximately $28 \%$ during missions with a range of $926 \mathrm{~km}$ (500 nautical miles) [3]. According to information in the literature [3], in case of using hydrogen fuel in long range airplanes, the loss of energy efficiency will amount about $2 \%$ at a distance of about $5556 \mathrm{~km}$ (3000 nautical miles). It will be caused by the smaller take-off weight of the aircraft, resulting from the low mass of hydrogen fuel.

\subsection{Liquid hydrogen}

Hydrogen is characterized by clean combustion, high flame speed, wide burning limits, easy ignition and very good cooling capacity. Comparing properties of kerosene, hydrogen and methane, presented in Table 1, hydrogen has about 2.7 time higher energy content per unit mass than kerosene, and about 2.4 time higher than methane. To the main hydrogen disadvantages can be included low density per unit volume and low boiling point. The other problem is issue that hydrogen production is costly. Currently the most economically production of hydrogen is by steam reforming of natural gas, partial oxidation of methane or coal gasification. Electrolysis of water is another source of hydrogen but is inefficient and expensive [7].

\subsection{Liquid methane}

Liquid methane is the other candidate for alternative aviation fuel. Cooling capacity of liquid methane are not as large as for hydrogen, but are higher than for conventional fuel used in turbine engines. The specific energy of liquid 
methane is higher as compared with kerosene (Table 1). Methane is also characterized by good thermal stability and clean combustion [7].

The disadvantage of this type of fuel will be low density and low boiling point. Methane require about $70 \%$ more volume to storage than kerosene. This may result in problems with aircraft configuration, due to considerable size of fuel tanks [7]. Because methane is also cryogenic fuel like hydrogen, both of this fuels will be accompanied by similar problems, for example such as losses of fuel due to vaporization.

The comparison of selected properties of kerosene, liquid hydrogen and liquid methane are presented in Table 1.

Table. 1. Properties of selected fuels [7]

\begin{tabular}{|l|c|r|r|r|}
\hline \multicolumn{1}{|c|}{ Property } & Unit & $\begin{array}{c}\text { Kerosene } \\
\mathrm{C}_{11} \mathrm{H}_{21}\end{array}$ & $\begin{array}{c}\text { Liquid } \\
\text { Hydrogen } \\
\mathrm{H}_{2}\end{array}$ & $\begin{array}{c}\text { Liquid } \\
\text { Methane } \\
\mathrm{CH}_{4}\end{array}$ \\
\hline $\begin{array}{l}\text { Lower specific } \\
\text { energy }\end{array}$ & $\mathrm{MJ} / \mathrm{kg}$ & 42.8 & 116 & 49 \\
\hline Cooling capacity & $\mathrm{MJ} / \mathrm{kg}$ & $0.38-0.85$ & 20.2 & 2.55 \\
\hline Specific heat & $\mathrm{kJ} /(\mathrm{kg} \cdot \mathrm{K})$ & 1.97 & 7.32 & 3.43 \\
\hline Flame speed & $\mathrm{m} / \mathrm{s}$ & 0.39 & 2.67 & 0.37 \\
\hline Boiling point & $\mathrm{K}$ & $423-573$ & 21 & 111 \\
\hline Freezing point & $\mathrm{K}$ & 223 & 13 & 91 \\
\hline Relative density & $289-289 \mathrm{~K}$ & 0.8 & 0.071 & 0.424 \\
\hline
\end{tabular}

\section{Combustion process}

Aircraft turbine engines require high combustion efficiency at wide range of operating conditions, from see level to $11 \mathrm{~km}$ of ceiling for civil aircraft. Combustion process should be free from pressure pulsation and combustion instabilities. Fuel ignition should be reliable in both, take off and cruise conditions, especially at low ambient temperature and in case of turbine engine flameout at high altitude [4].

The reaction of fuel combustion should progress with sufficient amount of oxygen. This process is connected with the definition of stoichiometric ratio. Stoichiometric ratio is the coefficient that define the complete combustion of hydrocarbon fuel which gives in results the complete conversion to $\mathrm{CO}_{2}$ and to $\mathrm{H}_{2} \mathrm{O}[4,8]$.

The equation of complete combustion of general hydrocarbon fuel with air can be write as follows [4]:

$$
\begin{gathered}
\mathrm{C}_{\mathrm{a}} \mathrm{H}_{\mathrm{b}}+\left(\mathrm{a}+\frac{\mathrm{b}}{4}\right)\left(\mathrm{O}_{2}+3.76 \mathrm{~N}_{2}\right)=\mathrm{aCO}_{2}+\frac{\mathrm{b}}{2} \mathrm{H}_{2} \mathrm{O}+ \\
+3.76\left(\mathrm{a}+\frac{\mathrm{b}}{4}\right) \mathrm{N}_{2}
\end{gathered}
$$

The stoichiometric fuel-air ratio (FAR) can be calculated from the reaction equation (1) [4]:

$$
\text { FAR }=\frac{\mathrm{C}_{\mathrm{a}} \mathrm{H}_{\mathrm{b}}}{\left(\mathrm{a}+\frac{\mathrm{b}}{4}\right)\left(\mathrm{O}_{2}+3.76 \mathrm{~N}_{2}\right)}
$$

It is easy to notice from equation (2) that FAR depends on the fuel composition. The lowest stoichiometric fuel-air ratio has hydrogen while the highest kerosene (Table 2).
Table 2. Stoichiometric FAR for selected fuels

\begin{tabular}{|c|c|c|c|}
\cline { 2 - 4 } \multicolumn{1}{c|}{} & \multicolumn{3}{c|}{ Fuel } \\
\cline { 2 - 4 } \multicolumn{1}{c|}{} & Kerosene & Methane & Hydrogen \\
\hline FAR & 0.069 & 0.058 & 0.029 \\
\hline
\end{tabular}

The dependence of actual fuel-air ratio to stoichiometric fuel-air ratio is defined as fuel-air equivalence ratio, and is describe by equation (3) [4]:

$$
\phi=\frac{(\text { Fuel/Air })_{\text {actual }}}{(\text { Fuel/Air })_{\text {stoichiometric }}}
$$

For stoichiometric mixture $\phi=1$. When $\phi<1$ the mixture is referred to lean or weak, and is characterize by excess of air. For fuel reach mixture $\phi>1$, and due to the deficiency of oxygen, the combustion process is incomplete [4].

The reaction rate in the combustion chamber depends considerable on two parameters: static pressure $(\mathrm{P})$ and temperature $(\mathrm{T})$. At low pressure the reaction rate proceed slowly. This process may become limited at high altitudes where the pressure is lower than on the ground. The other factors that affected combustion are the rate at which the fuel is vaporized and mixed with air [4].

Product resulting from the combustion process depend on the composition of applied fuel. The chemical equation of complete combustion of selected fuels with air can be write as follows:

- for kerosene (with an approximate pattern $\mathrm{C}_{11} \mathrm{H}_{21}$ [7]):

$$
\begin{gathered}
\mathrm{C}_{11} \mathrm{H}_{21}+16.25\left(\mathrm{O}_{2}+3.76 \mathrm{~N}_{2}\right) \rightarrow 11 \mathrm{CO}_{2}+10.5 \mathrm{H}_{2} \mathrm{O}+ \\
+61.1 \mathrm{~N}_{2}
\end{gathered}
$$

- for hydrogen $\left(\mathrm{H}_{2}\right)$ :

$$
\mathrm{H}_{2}+0.5\left(\mathrm{O}_{2}+3.76 \mathrm{~N}_{2}\right) \rightarrow \mathrm{H}_{2} \mathrm{O}+1.88 \mathrm{~N}_{2}
$$

- for methane $\left(\mathrm{CH}_{4}\right)$ :

$$
\mathrm{CH}_{4}+2\left(\mathrm{O}_{2}+3.76 \mathrm{~N}_{2}\right) \rightarrow \mathrm{CO}_{2}+2 \mathrm{H}_{2} \mathrm{O}+7.52 \mathrm{~N}_{2}
$$

The main products release during kerosene combustion are carbon monoxide $(\mathrm{CO})$, carbon dioxide $\left(\mathrm{CO}_{2}\right)$, nitrogen dioxides $\left(\mathrm{NO}_{\mathrm{x}}\right)$, water vapor $\left(\mathrm{H}_{2} \mathrm{O}\right)$, unburned hydrocarbons (UHC), sulfur oxides $\left(\mathrm{SO}_{\mathrm{x}}\right)$ and smoke. In contrast to hydrocarbon fuels hydrogen is named 'clean' energy carrier, due to low emission of combustion gases. During the combustion of hydrogen fuel are released water vapor, in the amount 2,5 times greater than for kerosene, and nitrogen dioxides. Methane is also characterized by clean combustion due to its low carbon content [7].

\section{Turbofan aircraft engine with inter turbine burner}

The concept of turbo jet engine with inter-turbine burner (ITB) was extensively studied by two researches: Sirignano and Liu [6]. Authors consider two concepts of ITB: one as continuous burning in the turbine and second as discrete interstage turbine burners $[4,6]$. They carried out thermodynamics analysis of turbojet and turbofan engine showed the advantages of using ITB. The advantages of that engine configuration is improvement of engine thermal efficiency and reduction of $\mathrm{NO}_{\mathrm{x}}$. Researches on the possibility of improving turbojet and turbofan engines performance by using additional combustion chamber situated between 
turbine stages started in the late 1990s and are still being continued [4].

In conducted research ITB is a part of conventional turbofan engine design, located between the high pressure turbine (HPT) and the low pressure turbine (LPT) (Fig. 1).

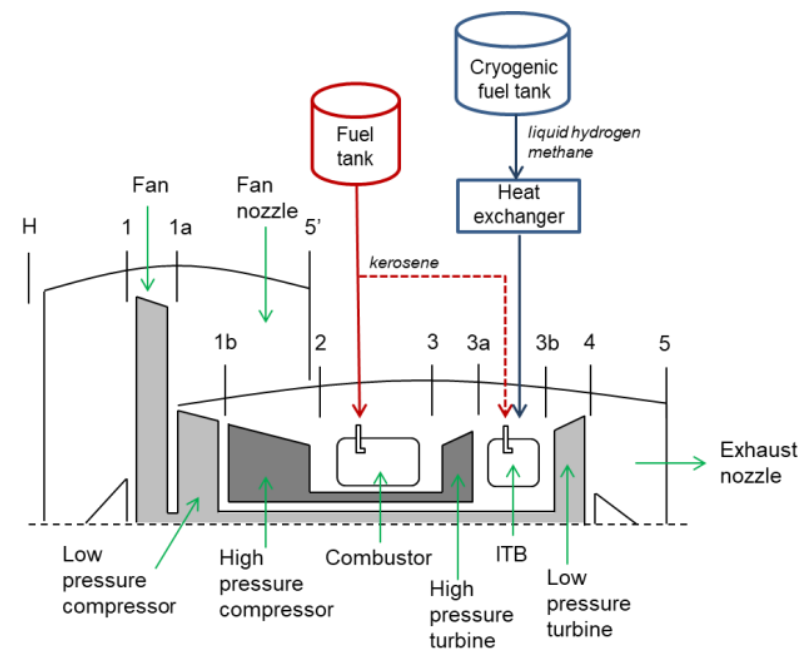

Fig. 1. Turbofan engine scheme

Actual fuel-to-air ratio relation for additional combustion chamber was calculated based on the energy balance [4].

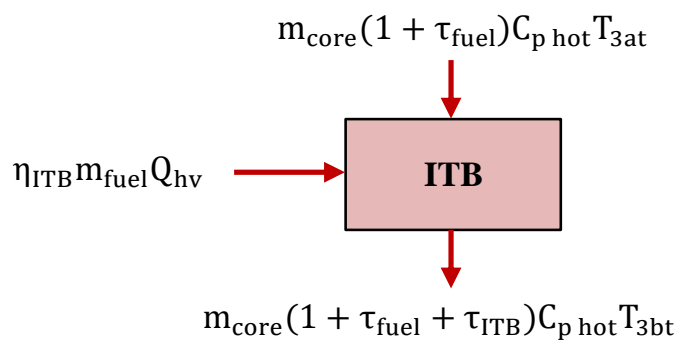

Fig.2. Energy balance for inter turbine burner

Actual fuel-air ratio for ITB:

$$
\tau_{\text {ITB }}=\frac{\left(\mathrm{T}_{3 \mathrm{bt}}-\mathrm{T}_{3 \mathrm{at}}\right) \cdot\left(1+\tau_{\mathrm{fuel}}\right) \cdot \mathrm{C}_{\mathrm{phot}}}{\mathrm{Q}_{\mathrm{hv}} \cdot \eta_{\text {ITB }}-\mathrm{C}_{\mathrm{p} \mathrm{hot}} \cdot \mathrm{T}_{3 \mathrm{bt}}}
$$

where: $\tau_{\text {fuel }}$ - actual fuel-air ratio refer to main combustion chamber, $\mathrm{T}$ - total temperature at given engine section (see Fig. 1), $C_{p \text { hot }}-$ specific heat of hot gases, $C_{p}$ cold - specific heat of air, $\eta_{\text {ITB }}-$ ITB efficiency, $Q_{h v}-$ fuel heating value.

The temperature at the outlet of the LPT was calculated from the energy balance for low pressure spool, in accordance with the following relation [4]:

$$
\mathrm{P}_{\mathrm{F}}+\mathrm{P}_{\mathrm{LPC}}=\eta_{\mathrm{m}} \cdot \mathrm{P}_{\mathrm{LPT}}
$$

where: $\mathrm{P}_{\mathrm{F}}-$ fan power, $\mathrm{P}_{\mathrm{LPC}}-$ high pressure compressor power, $P_{L P T}-$ high pressure turbine power, $\eta_{m}-$ mechanical efficiency.

From relation (8), the temperature at the outlet of the low pressure turbine (LPT) is defined by the following equation (9):

$$
\begin{array}{r}
\mathrm{T}_{4 \mathrm{t}}=\mathrm{T}_{3 \mathrm{t}}-\left[\frac{(1+\mu) \cdot \mathrm{m}_{\text {core }} \cdot \mathrm{C}_{\mathrm{p} \mathrm{cold}} \cdot\left(\mathrm{T}_{1 \mathrm{at}}-\mathrm{T}_{1 \mathrm{t}}\right)}{\mathrm{m}_{\text {core }} \cdot\left(1+\tau_{\text {fuel }}\right) \cdot \eta_{\mathrm{m}} \cdot \mathrm{C}_{\mathrm{p} \mathrm{hot}}}+\right. \\
\left.\quad+\frac{\mathrm{m}_{\text {core }} \cdot \mathrm{C}_{\mathrm{p} \mathrm{cold}} \cdot\left(\mathrm{T}_{1 \mathrm{bt}}-\mathrm{T}_{1 \mathrm{at}}\right)}{\mathrm{m}_{\text {core }} \cdot\left(1+\tau_{\text {fuel }}\right) \cdot \eta_{\mathrm{m}} \cdot \mathrm{C}_{\mathrm{phot}}}\right]
\end{array}
$$

The performance of the jet engine describe fundamentals parameters such as specific thrust and specific fuel consumption. To calculate both of these indicators it is necessary to know engine thrust force.

Engine thrust force for turbofan engine with additional combustor chamber may be expressed by equation:

$$
\mathrm{T}=\mathrm{m}_{\mathrm{h}} \mu \mathrm{V}_{5}^{\prime}+\mathrm{m}_{\mathrm{h}}\left(1+\mathrm{f}+\mathrm{f}_{\mathrm{tb}}\right) \mathrm{V}_{5}-\mathrm{m}_{\mathrm{h}}(1+\mu) \mathrm{V}
$$

where: $\mathrm{V}$ - velocity of the flight, $\mathrm{V}_{5}$ - velocity of exhaust gases (hot nozzle), $\mathrm{V}_{5}$ '- velocity of bypass air (cold nozzle), $\mu$ - bypass ratio, $m_{h}-$ mass flow rate passing through the main engine core, $\mathrm{f}-$ fuel to air ratio, $\mathrm{f}_{\mathrm{tb}}-$ fuel to air ratio refer to turbine burner.

Specific thrust is defined as a relation between engine thrust and mass flow rate:

$$
\mathrm{ST}=\frac{\mathrm{T}}{\mathrm{m}_{\mathrm{h}}}
$$

Specific fuel consumption is defined as the fuel flow rate per unit thrust and can be expressed by following equation:

$$
\mathrm{SFC}=\frac{\mathrm{m}_{\mathrm{fuel}}}{\mathrm{T}}
$$

where: $\mathrm{m}_{\mathrm{fuel}}-$ total fuel burn in both combustor chambers, $\mathrm{T}$ - engine thrust.

\section{Scope of the work}

The main scope of presented paper is performance analysis of turbofan engine with additional combustor chamber fueled by alternative fuel. Main combustor chamber is supply by conventional aircraft fuel. As an alternative fuels were chose cryogenic fuels such as liquid hydrogen and liquid methane. The thermodynamics model of turbofan engine with dual combustor chamber was implemented in Matlab software. Engine performance analysis was carried out for take-off conditions (off-design) as the most critical stage of the flight. The working gas was modeled using a semi-perfect gas model. Properties of the exhaust gases were modeled based on the reference [5]. The turbine cooling process was not taken into consideration. Turbine inlet temperature (TIT) for high pressure turbine was assumed as $\mathrm{T}_{3}=1500 \mathrm{~K}$, whereas for low pressure turbine as $\mathrm{T}_{3 \mathrm{~b}}=$ $1300 \mathrm{~K}$. Configuration of turbofan engine with ITB and marked characteristic engine cross-sections is presented on Fig. 1. The thermodynamic model was elaborate based on the equation describing the work of main engine components, based on the reference $[4,5,9]$.

Input parameters necessary for engine performance analysis are presented in Table 3. 
Table 3. Input parameters for engine performance analysis

\begin{tabular}{|l|c|c|c|}
\hline \multicolumn{1}{|c|}{ Property } & Description & Unit & Take-off \\
\hline Altitude & $\mathrm{H}$ & $\mathrm{m}$ & 0 \\
\hline Velocity of flight & $\mathrm{Ma}$ & - & 0 \\
\hline Air mass flow & $\mathrm{m}$ & $\mathrm{kg} / \mathrm{s}$ & 670 \\
\hline Fan pressure ratio & $\pi_{\mathrm{F}}$ & - & 1.65 \\
\hline Bypass ratio & $\mu$ & - & 4.4 \\
\hline Low pressure compressor ratio & $\pi_{\mathrm{LPC}}$ & - & 1.6 \\
\hline High pressure compressor ratio & $\pi_{\mathrm{HPC}}$ & - & 12.8 \\
\hline Overall pressure ratio & $\pi$ & - & 33.8 \\
\hline HPT turbine inlet temperature & $\mathrm{T}_{3}$ & $\mathrm{~K}$ & 1500 \\
\hline LPT turbine inlet temperature & $\mathrm{T}_{3 \mathrm{~b}}$ & $\mathrm{~K}$ & 1300 \\
\hline
\end{tabular}

Additional combustor chamber will use the air with large content of combustion gases, similar like afterburner [4].

The stoichiometric equation allow to calculate the amount of air necessary to burn given amount of fuel. Obtained results indicate that implementation of hydrogen will reduce the required air necessary to complete combustion and will allow for reduction of engine diameter. This will result in lower engine mass and lower drag force caused by the engine overall dimensions and increase the range of the flight.

\section{Result discussion}

Results of conducted analysis are presented in Table 4 and Table 5. All fuels applied in additional combustor chamber represent lean-fuel mixture (Table 2). For take-off conditions, the highest value of specific thrust (ST) is obtained for turbofan engine with ITB supplied by hydrogen. The lowest value is exceeded for kerosene fuel, which is caused by the differences in heat value of each applied fuel. Due to large heat value of hydrogen fuel (Table 1), the fuelto-air ratio is lower than for other selected fuels, which implies lower fuel consumption by the engine.

Table 4. Results of thermodynamics analysis of modified turbofan engine configuration

\begin{tabular}{|c|c|c|c|c|c|}
\hline & \multicolumn{3}{|c|}{ Turbofan engine with ITB } \\
\hline & & & Kerosene & $\mathrm{LH}_{2}$ & Methane \\
\hline Specific thrust & $\mathrm{kj}$ & {$[\mathrm{Ns} / \mathrm{kg}]$} & 392.19 & 423.77 & 409.13 \\
\hline $\begin{array}{l}\text { Specific fuel } \\
\text { consumption }\end{array}$ & cj & {$[\mathrm{kg} / \mathrm{Ns}]$} & $1.16 \cdot 10^{-5}$ & $9.35 \cdot 10^{-6}$ & $1.09 \cdot 10^{-5}$ \\
\hline Engine thrust & $\mathrm{K}$ & {$[\mathrm{kN}]$} & 262.77 & 283.93 & 274.12 \\
\hline Fuel-air-ratio & $\tau_{\text {fuel }}$ & - & & & 0.0195 \\
\hline Fuel-air-ratio & $\tau_{\mathrm{ITB}}$ & - & 0.0050 & 0.0018 & 0.0044 \\
\hline Fuel mass flow & $\mathrm{m}_{\text {fuel }}$ & {$[\mathrm{kg} / \mathrm{s}]$} & & & 2.43 \\
\hline Fuel mass flow & $\begin{array}{c}\mathrm{m}_{\text {fuel }} \\
\text { ITB }\end{array}$ & {$[\mathrm{kg} / \mathrm{s}]$} & 0.63 & 0.23 & 0.55 \\
\hline $\begin{array}{l}\text { Exhaust mass } \\
\text { flow }\end{array}$ & $\mathrm{m}_{\text {hot }}$ & {$[\mathrm{kg} / \mathrm{s}]$} & 127.13 & 126.73 & 127.05 \\
\hline $\begin{array}{l}\text { Velocity of } \\
\text { exhaust gases }\end{array}$ & $\mathrm{c}_{5}$ & $\mathrm{~m} / \mathrm{s}$ & 734.57 & 903.85 & 824.38 \\
\hline $\begin{array}{l}\text { Velocity of } \\
\text { cold gases }\end{array}$ & $\mathrm{c}_{5^{\prime}}$ & $\mathrm{m} / \mathrm{s}$ & & & 310.27 \\
\hline
\end{tabular}

Additional analysis was carried out, to compare the effect of the additional combustion chamber on the performance of conventional engine design. The results are presented in Table 5.
Application of additional combustion chamber affects the increase in thrust value generated by the turbine engine. Comparing the classical configuration of turbofan engine with modified configuration with ITB supplied by kerosene, the engine specific thrust was increased by $4.2 \%$. For the case of suppling the additional combustion chamber by hydrogen, engine specific thrust increased by $12.6 \%$ and by methane by $8.7 \%$. Interesting is the fact that the specific fuel consumption (SFC) for modified engine is slightly lower than for conventional engine design. SFC is defined as the fuel flow rate per unit thrust. For the engine with additional combustion chamber, fuel flow rate is higher by the value of fuel mass flow in additional combustor. Engine thrust express by a formula (7) depends on the velocity of exhaust gases, which is about 38\% higher for engine with dual combustor system than for base design. In addition obtained engine thrust is higher so in accordance with relation (9), the SFC must decreased. SFC is very important factor that describe engine economy.

Table 5. Results of thermodynamics analysis of modified turbofan engine configuration

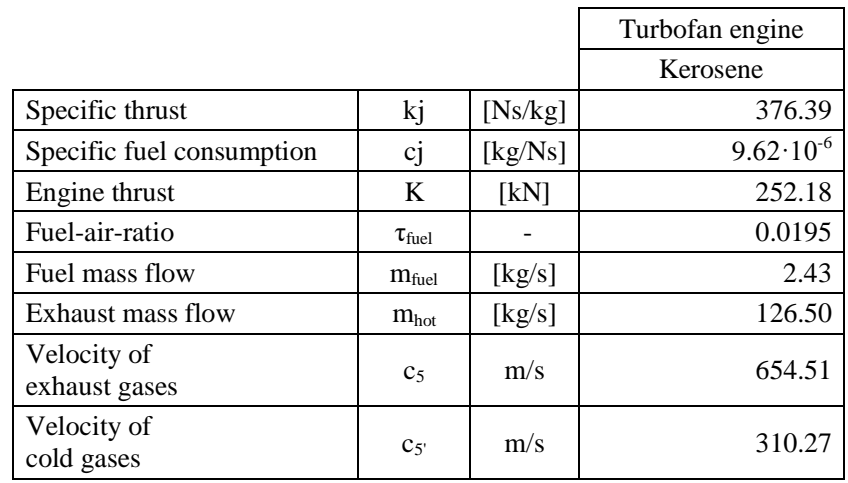

The relationship between engine unit parameters and engine overall pressure ratio is presented on Fig. 3, for base and modified engine. For classical configuration of turbofan engine, the maximum of ST is exceed for lower values of engine pressure ratio than for configuration with additional source of heat. In addition after reaching the maximum, the value of ST decrease violently in comparison with the graphs that describe the changes of ST with engine pressure ratio for modified engine configuration.

The highest values of ST with simultaneous the lowest values of SFC are obtained for engine configuration with dual combustor chamber, supplied by the hydrogen.

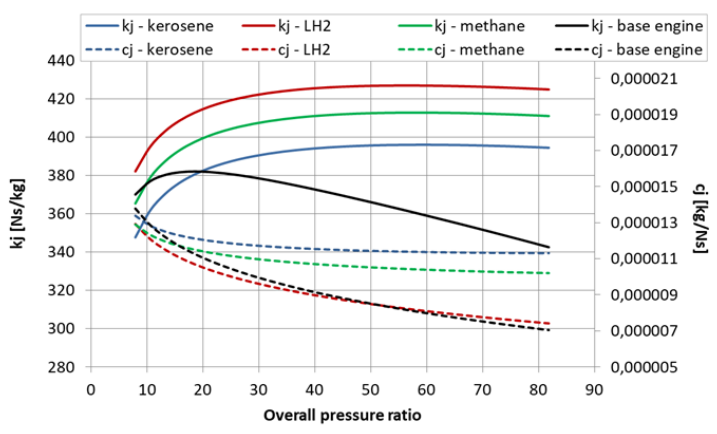

Fig. 3. Specific thrust and specific fuel consumption in function of engine pressure ratio 
The relationship between engine unit parameters and LPT inlet temperature is presented on Fig. 4. In general, the ST is increase with the inlet turbine temperature increase, which is accompanied by the growth of specific fuel consumption. It is noticeable that the growth of SFC in case of application hydrogen fuel is lower than for kerosene and methane at given TIT. The highest values of specific thrust with simultaneous the lowest value of specific fuel consumption are obtained for hydrogen, which is caused by its properties. Even for higher temperature values, the SFC for hydrogen is much smaller than for kerosene and methane.

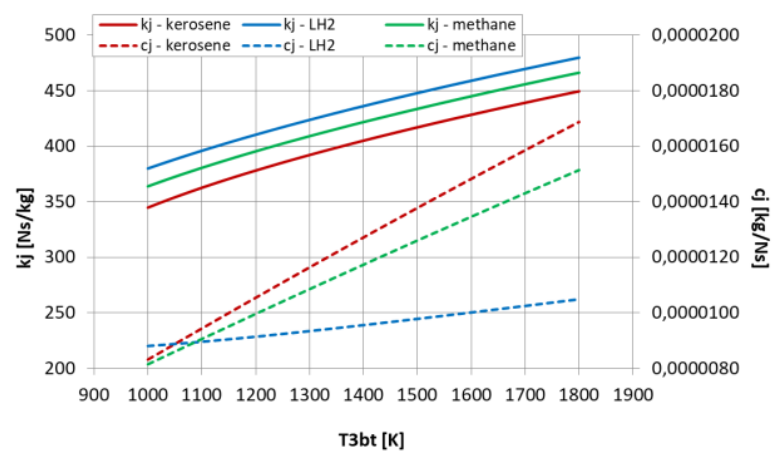

Fig. 4. Specific thrust and specific fuel consumption in function of LPT inlet temperature

\section{Conclusions}

Engine design with additional combustion chamber situated between HPT and LPT is very promising concept for future turbine engines. Such engine configuration allows for increase in engine specific thrust. Application of inter turbine burner require assurance stable fuel combustion, safety and engine reliability. Feeding ITB by alternative fuel with high energy content, exert significant influence on engine performance. Application of alternative fuel will complicate aircraft design, especially in case of application cryogenic fuels, due to its high storage requirements. In addition, application of two different kinds of fuels will require two separate fuel tanks with separate feeding systems.

Exploration of new technological solutions in aero engines is necessary from the point of view of increasing the performance of modern aircraft engines as well as from the point of view of environmental protection.

Conducted researches presented the influence of the ITB fueled by selected fuels, on engine performance. At the level of further researches, particular attention should be paid to the operational characteristics of the turbofan engine with inter turbine burner supplied by different types of fuel.

\section{Nomenclature}

HPT high pressure turbine

ITB inter turbine burner

LPT low pressure turbine
SFC specific fuel consumption

ST specific thrust

TIT turbine inlet temperature

\section{Bibliography}

[1] BUFFI, M.,CHIARAMONTI, D., VALERA-MEDINA, A. Strategies toward experimental assessments of new aviation renewable fuels and blends: the BIOREFLY project, Energy Procedia. 2017, 105, 433-438.

[2] DAGGETT, D.L., HENDRICKS, R.C.,WALTHER, R.C., CORPORAN, E. Alternative fuels for use in commercial aircraft. 2007.

[3] DAGGETT, D.L., HADALLER, O., HENDRICKS, R.C., WALTHER, R.C. Alternative fuels and their potential impact on aviation, NASA/TM-2006-214365, 2006.

[4] EL-SAYED, A.F. Aircraft propulsion and gas turbine engines. CRC Press. 2017.

[5] JAKUBOWSKI, R. Analysis of chosen fuels influence on turboprop engine work performance. Journal of KONES Powertrain and Transport. 2016, 23(2). DOI: 10.5604/ 12314005.1213586 .
[6] LIU, F., SIRIGNANO, W.A. Turbojet and turbofan engine performance increase through turbine burners. Journal of Propulsion and Power. 2001, 17(3).

[7] LEFEBVRE, A.H., BALLAL, D.R. Gas turbine combustion - alternative fuels and emissions, $3^{\text {rd }}$ edition. CRC Press. 2010.

[8] ŁAPUCHA, R. Komory spalania silników turbinowo-odrzutowych. Procesy, obliczenia, badania. Wydawnictwa Naukowe Instytutu Lotnictwa. Warszawa 2004.

[9] SARAVANAMUTTO, H., ROGERS, G., COHEN, H., STRAZNICKY, P. Gas turbine theory. Pearson Prenticle Hall. 2009.

[10] Air Transport Action Group (ATAG), Beginner's Guide to Aviation Biofuels, $2^{\text {nd }}$, Geneva 2011.

\footnotetext{
Natalia Marszałek, MEng. - Faculty of Fluid Mechanics and Aerodynamics, Rzeszow University of Technology.

e-mail: n.marszalek@prz.edu.pl
} 